\title{
USING THE RESILIENCE APPROACH IN THE RESOCIALIZATION OF CHILDREN FROM FAMILIES IN DIFFICULT LIFE SITUATIONS
}

\author{
Alla Kovalchuk', Halyna Herasym ${ }^{2}$ \\ Lviv Polytechnic National University, Lviv, Ukraine \\ ${ }^{1}$ Student of master program "Social Work", of Department of Sociology and Social Work \\ ${ }^{2}$ Senior Lecturer of the Department of Sociology and Social Work
}

Background: The topic of resilience or psychological elasticity is being raised quite actively at the moment. Many researchers in the field of social work, psychology, pedagogy and neuroscience see this as an inexhaustible potential, because resilience is a characteristic that can be developed and improved, just to intervene with correction in childhood. The family is a social institution that reflects the main values, needs and problems of the population. Depending on how the child's socialization takes place in the family circle, how successfully or not the processes of mental, physical, spiritual, and social development of the child take place - determine the further response and functioning of the child in society to various factors (stress, unforeseen situations, and so on).

Purpose: to identify the features of the application of the approach of resilience in social work with children who are in difficult situations;

Methods: The classification method was used to recalculate factors that will support a child's positive adaptation. The historical method was used to review studies of factors that form resilience in children.

Results: Elements of the formation of resilience are self-esteem, self-confidence, self-support, family support, close friends, a positive atmosphere in the family, the presence of hobby, the presence of attention from at least one adult, religiosity, spiritual values, psychological well-being were emphasized. Such factors contribute to positive adaptation during difficult life situations and they are individual for everyone. For each person there is an individual factor that helps to survive difficult life situations better.

Conclusion: The work of a social worker with children who are in difficult life situations is aimed at finding the strengths of the child. The main factors that allow you to pass the stage of difficult life situations are internal and external resources. In other words, we can say that resilience is formed by both the risks that create a stressful situation, and positive factors that help to overcome emergencies and strengthen resistance. The approach is aimed at the successful functioning and development of a child or adolescent, despite difficult life circumstances and associated risks.

Keywords: resilience, resilient, stability, difficult life situations, social work.

Тема резильєнтності або ж психологічної пружності підіймається на разі досить активно. Багато дослідників в галузях соціальної роботи, психології, педагогіки та нейробіології бачать в цьому невичерпний потенціал, адже резильєнтність - характеристика, яку можна розвивати та вдосконалювати, всього лиш втрутитись 3 корекцією в дитячому віці. Сім'я $\epsilon$ соціальним інститутом, в якому відображаються головні цінності, потреби та проблеми населення. В залежності від того, як відбувається соціалізація дитини в колі сім’ї, наскільки успішно чи не успішно проходять процеси психічного, фізичного, духовного, соціального розвитку дитини - визначають подальше реагування та функціонування дитини в соціумі на різні подразнення (стрес, непередбачувані обставини тощо).

Однією $з$ перших хто почав вивчати резилієнс стала доктор філософії та професор психології Е.Вернер. Вона провела одне значиме дослідження тривалістю в 30 років i охоплення 700 людей 3 моменту народження та до третього десятку іхнього життя. Дві третини дітей були $з$ успішних, забезпечених сімей, а інші - класифікувались як ті «що знаходяться в групі ризику», тобто були вихідцями з сімей, які матеріально незабезпечені, нестабільні, мали проблеми з психічним здоров'ям, алкоголем тощо (Mudrecka, 2013). Гіпотезою дослідження стала думка, що діти, які найбільше піддаються ризикам (наприклад наркозалалежні батьки, які кривдять свою дитину або передчасні роди в поєднанні 3 
психічно нестабільною матір'ю) - в дорослому житті набагато частіше опиняються в складних життєвих ситуаціях та мають проблеми зі злочинністю, наркотичними речовинами, стосунками в сім'ї, аніж діти, що мають нижчу схильність до ризиків (Kirsten, 2017). В результаті дослідження виявили, що третина дітей, з високим ризиком продемонстрували протилежно обернені результати в дорослому житті. Дорослі учасники виявили резильєнтність та були соціально-успішними в житті, впевненими в своїх силах, та мали міцні сімейні стосунки.

Отже, на основі цього дослідження було перераховано чинники, що розвивають відновлення, відчуття позитивної адаптації після/під час складних життєвих обставин. Такими чинниками є: включає в себе критичне мислення, опірність до негативних ситуацій, здатність мислити позитивно та вірити « в краще», міцні, благополучні відносини з друзями, батьками, успіхи в навчальному середовищі. В таких випадках, коли складні життєві обставини припускають наявність ризиків, науковці наполягають на зміщенні фокусу уваги: не на недоліки дитини та речі, які вона не вміє, натомість обрати фокус на сильні сторони дитини (Fergus, \& Zimmerman, 2005), що в неї виходить добре, як вона справляється 3 самостійними дорученнями. Завдяки оточенню та зовнішнім ресурсам ситуація постає не такою складною, здається, що пережити ії стає простіше.

Роберт Опора (2010) у корекційній роботі з дітьми пропонує соціальному працівникові, педагогам сконцентрувати увагу на виявленні захисних факторів, що будуть підтримувати позитивну адаптацію дитини. Він виділяє наступні захисні фактори:

Зовнішні фактори захисту:

1. Почуття елементарної стабільності і безпеки поряд з дорослим;

2. Шкільна освіта (шукати напрямки, де дитина сильна і може себе проявляти найкраще, що дасть відчуття задоволеності та наснаги);

3. Відносини між однолітками ( позитивна комунікація в оточенні підлітків є важливим фактором отримання інформації про себе та інших, задоволенні власних потреб, вивченні потреб інших і принципів міжособистісного обміну).

Внутрішні фактори захисту:

1. Здібності та інтереси (відкриття людиною здібностей та інтересів і їх розвиток сприяє формуванню психологічної стійкості, на їх основі людина зміцнює свою самооцінку, надає орієнтири для життєвих цілей);

2. Система цінностей (дає людині розуміння хорошого і поганого, вони вирішують силу мотивації до дії, цінностями керуються, щоб боротися за те, що для людини є бажаним, i, крім того, створюють механізми самоконтролю);

3. Соціальна компетентність (наявність і застосування здатності інтегрованого мислення, почуття і поведінки для соціальної реалізації).

Тобто, можна сказати, що, резилієнс формують як і ризики, що створюють стресову ситуацію, так i позитивні чинники, що допомагають долати надзвичайні ситуації та зміцнювати резильєнтність. Підхід націлений на успішне функціонування та розвиток дитини, підлітка, попри складні життєві обставини та пов’язані з ними ризики.

\section{References}

Fergus, S., \& Zimmerman, M. (2005). Adolescent resilience: A framework for understanding healthy development in the face of risk. Anual Review of Public Health, 26, 399-404.

Kirsten,W.(2017).Maximizing children's resilience. URL: https://www.apa.org/monitor/2017/09/cover-resilience

Mudrecka, I. (2013). Wykorzystanie koncepcji resilience w profilaktyce niedostosowania społecznego i resocjalizacji. Warszawa, 49-61.

Opora R., Resocjalizacja: wychowanie i psychokorekcja nieletnich niedostosowanych społecznie, Kraków 2010. 


\section{Список використаної літератури:}

Fergus, S., \& Zimmerman, M. (2005). Adolescent resilience: A framework for understanding healthy development in the face of risk. Anual Review of Public Health, 26, 399-404.

Kirsten, W. (2017). Maximizing children's resilience. URL: https://www.apa.org/monitor/2017/09/cover-resilience

Mudrecka, I. (2013). Wykorzystanie koncepcji resilience w profilaktyce niedostosowania społecznego i resocjalizacji. Warszawa, 49-61.

Opora R., Resocjalizacja: wychowanie i psychokorekcja nieletnich niedostosowanych społecznie, Kraków 2010.

\section{Contact information:}

Алла Ковальчук

kovalchukalla358@gmail.com 